\title{
Analisis Kestabilan Model Host-Vector Transmisi HIV/AIDS Pada Pengguna Jarum Suntik
}

\author{
Jafaruddin (Alm) \\ Jurusan Matematika Universitas Nusa Cendana \\ Rapmaida M. Pangaribuan \\ Jurusan Matematika Universitas Nusa Cendana \\ Email: rapmaida_pangaribuan@yahoo.com \\ Aryanto \\ Jurusan Matematika Universitas Nusa Cendana \\ Email: arirakatesa@gmail.com \\ Irena A. Henukh \\ Jurusan Matematika Universitas Nusa Cendana \\ Email: irena_henukh@yahoo.com
}

\begin{abstract}
HIV/AIDS is a very dangerous disease. The transmission of HIV/AIDS can be in three ways and one of them through a syringe. In this paper we describe SIR and SEIR Host-Vector model transmission of HIV/AIDS amongst populations of injecting drug users. From the existing model we obtained diseasefree equilibrium point and endemic equilibrium point. Then we study the stability conditions and sensitivity analysis of the $R_{0}$. The analysis shows if $R_{0}<1$ then the disease-free equilibrium point is stable and if $R_{0}>1$ then the endemic equilibrium point will be stable. We also obtained that parameter of probality hostvector infected with HIV/AIDS affects the increase of number infected HIV/AIDS.
\end{abstract}

Keywords: HIV/AIDS, Host-Vector Transmission, The Stability of Equilibrium Point.

\section{Pendahuluan}

Human Immunodeficiency Virus (HIV) adalah virus yang dapat menyebabkan Acquired Immune Deficiency Syndrome (AIDS). Kasus HIV di Indonesia pertama sekali ditemukan di Bali pada bulan April 1987 dan mengalami peningkatan yang signifikan pada tahun 2013 sebanyak 29.037 kasus dan tahun 2014 sebanyak 32.711 kasus. Kasus positif AIDS tahun 2013 sebanyak 10.163 kasus dan tahun 2014 mengalami penurunan menjadi 5.494 kasus. Hal ini diperkirakan karena sistem pelaporan yang belum optimal. Dari 5.494 kasus AIDS di Indonesia tahun 2014, 
sebanyak 182 jiwa (3,3\%) merupakan pengguna napza suntikan (IDU) (Kemenkes RI, 2014).

Penularan penyakit HIV/AIDS ini dapat melalui hubungan seksual, kontak langsung dengan darah penderita HIV, dan secara vertikal dari ibu pengidap HIV kepada bayinya. Model matematika sangat diperlukan untuk menganalisis penularan HIV/AIDS. Pada tahun 2011, Ram Naresh dan Dilep Sharma menggunakan model SIA untuk menganalisis penularan HIV/AIDS secara vertikal dari ibu ke bayinya dan waktu tundaan (time-delay). Tahun 2012, Abdallah S. Waziri juga membentuk model matematika penyebaran HIV/AIDS secara vertikal yaitu SIPTA (Susceptible-InfectionTreatment PreAIDS-AIDS).

Penelitian penyebaran HIV/AIDS diantara sesama pengguna jarum suntik dilakukan oleh Greenhalgh dan Hay pada tahun 1997 dengan melakukan modifikasi model Kaplan. Model yang digunakan dalam penelitian tersebut belum membagi hostvector dalam beberapa kompartemen. Di Indonesia Tahun 2004, Besral dkk juga melakukan penelitian dengan judul Potensi Penyebaran HIV dari Pengguna Napza Suntik ke Masyarakat Umum. Penelitian tersebut menggunakan data sekunder dari hasil survey oleh Pusat Penelitian Kesehatan Universitas Indonesia, potensi penularan pada penelitian tersebut menggunakan konsep probabilitas.

Penelitian ini bertujuan untuk menganalisa kestabilan titik ekuilibrium Model Host-Vector transmisi HIV/AIDS pada pengguna jarum suntik dimana populasi hostvector sudah dibagi dalam beberapa kompartemen dan mengkaji parameter-parameter mana yang paling berpengaruh terhadap $R_{0}$ nya , sehingga pencegahan ataupun treatment untuk mengurangi penyebaran HIV/AIDS pada pengguna jarum suntik dapat dilakukan.

\section{Data dan Metode}

Prosedur yang dilakukan dalam penelitian ini adalah menetapkan beberapa asumsi, kemudian membangun model SIR dan SEIR Host-Vector transmisi HIV/AIDS dalam pengguna jarum suntik. Dari model yang telah dibuat dicari titik ekuilibriumnya, kemudian dianalisis kestabilan titik ekuilibriumnya. Didefinisikan $R_{0}$ dengan menggunakan metode The Next Generation Matrix (NGM) [4]. Serta dilakukan analisis sensitivitas $R_{0}$ terhadap parameter-parameter yang mempengaruhi.

\section{Hasil dan Pembahasan}

\section{Model SIR dan SEIR Host-Vector Transmisi HIV/AIDS dalam Pengguna Jarum Suntik}

Dalam model SIR Host-Vector transmisi HIV/AIDS dalam pengguna jarum suntik, Populasi Host dibagi dalam 3 kompartemen, yaitu $S_{h}, I_{h}, R_{h}$. Dimana $S_{h}$ adalah populasi Susceptible Host yang merupakan populasi manusia yang sehat dan rentan 
terinveksi HIV pada kalangan pengguna narkoba melalui jarum suntik, $I_{h}$ adalah populasi Infected Host yang merupakan populasi yang terinveksi HIV dan $R_{h}$ adalah populasi Recovered Host merupakan populasi yang berada dalam masa pengobatan. Jumlah populasi Host diasumsikan konstan, $N_{h}=S_{h}+I_{h}+R_{h}$.

Populasi vector dibagi dalam 2 kompartemen, yaitu $S_{v}$ dan $I_{v} . S_{v}$ adalah Susceptible Vector dalam hal ini jarum suntik yang masih steril, dan $I_{v}$ adalah Infected Vector merupakan populasi vektor yang telah terinfeksi HIV/AIDS karena pengaruh dari populasi host yang telah terinfeksi HIV/AIDS. Jumlah populasi vektor pada periode waktu satu tahun diasumsikan konstan yaitu $N_{v}=S_{v}+I_{v}$.

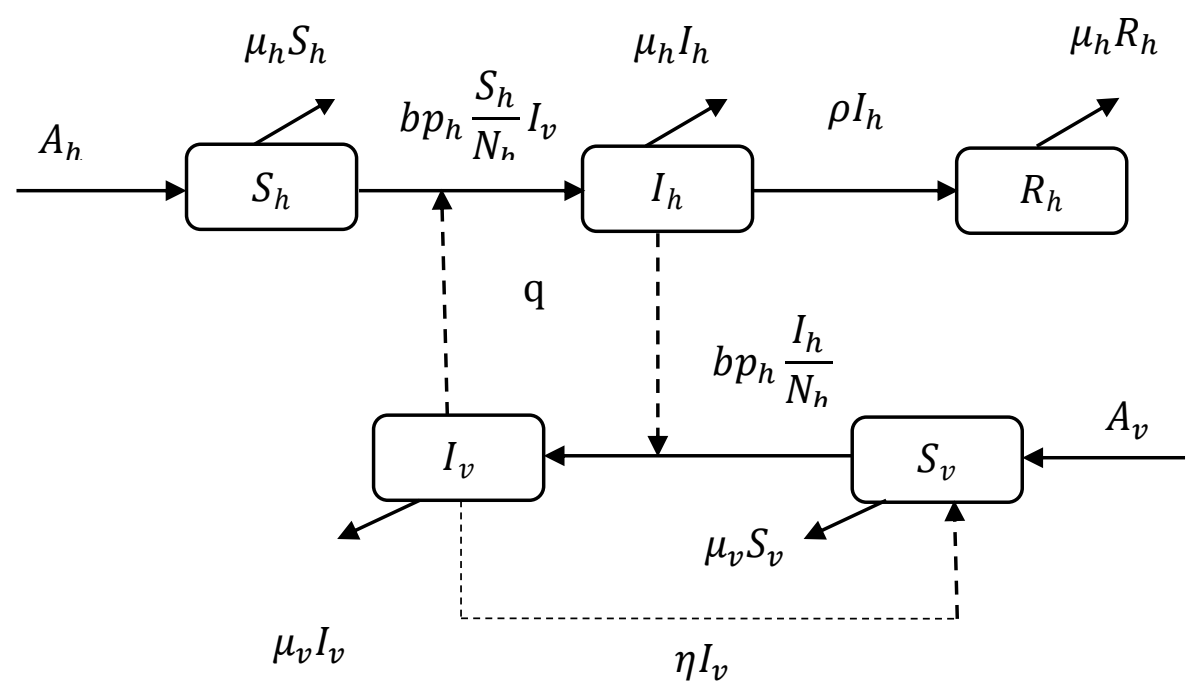

Gambar 1. Skema Model SIR Host-Vector Transmisi HIV/AIDS pada Pengguna Jarum Suntik

Berdasarkan Gambar 1, model matematika SIR Host-Vector Transmisi HIV/AIDS pada pengguna jarum suntik adalah sebagai berikut:

$$
\begin{aligned}
& \frac{d S_{h}}{d t}=A_{h}-b p_{h} \frac{S_{h}}{N_{h}} I_{v}-\mu_{h} S_{h} \\
& \frac{d I_{h}}{d t}=b p_{h} \frac{S_{h}}{N_{h}} I_{v}-\rho I_{h}-\mu_{h} I_{h} \\
& \frac{d R_{h}}{d t}=\rho I_{h}-\mu_{h} R_{h} \\
& \frac{d S_{v}}{d t}=A_{v}-b p_{v} S_{v} \frac{I_{h}}{N_{h}}+\eta I_{v}-\mu_{v} S_{v} \\
& \frac{d I_{v}}{d t}=b p_{v} S_{v} \frac{I_{h}}{N_{h}}-\eta I_{v}-\mu_{v} I_{v}
\end{aligned}
$$


dengan:

$A_{h}$ merupakan laju kelahiran alami dari populasi host, dengan $A_{h}>0$

$\mu_{h}$ merupakan laju kematian alami dari populasi host, dengan $\mu_{h}>0$

$\rho$ merupakan laju transisi dari kompartemen infective host ke kompartemen recovered host

$A_{v} \quad$ merupakan laju produksi populasi vektor yaitu jarum suntik

$\mu_{v}$ merupakan laju kerusakan jarum suntik

$b$ merupakan laju infeksi HIV/AIDS pada populasi Host dan Vector

$\eta \quad$ merupakan laju sterilisasi jarum suntik.

Selanjutnya pada model SEIR dengan menambahkan satu kompartemen populasi exposed, yaitu populasi yang berada dalam masa inkubasi dibentuk skema model sebagai berikut:

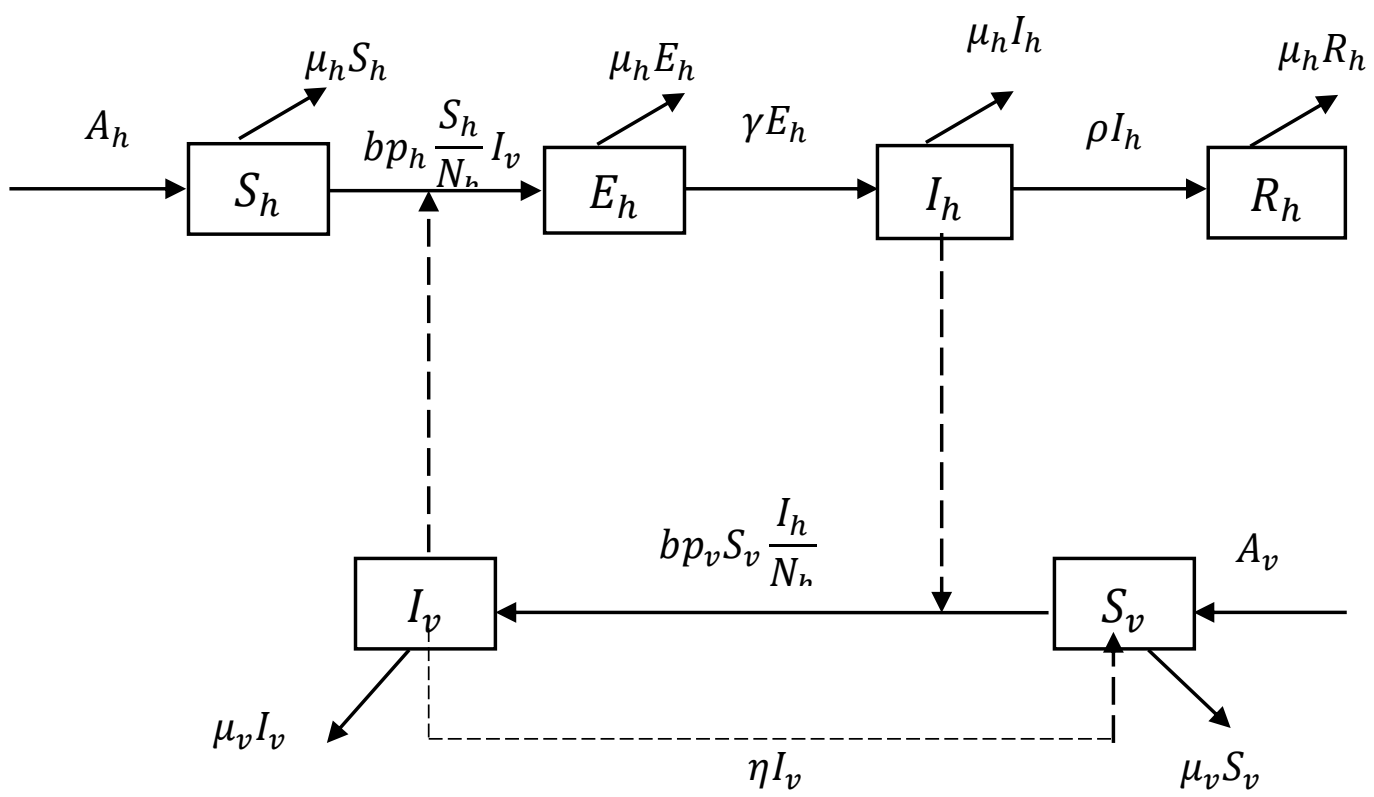

Gambar 2. Skema Model SEIR Host-Vector Transmisi HIV/AIDS pada Pengguna Jarum Suntik

Pada Gambar 2 terdapat parameter $\gamma$ yang merupakan laju inkubasi populasi host, berdasarkan skema tersebut dibentuk model matematika sebagai berikut: 


$$
\begin{aligned}
& \frac{d S_{h}}{d t}=A_{h}-b p_{h} \frac{S_{h}}{N_{h}} I_{v}-\mu_{h} S_{h} \\
& \frac{d E_{h}}{d t}=b p_{h} \frac{S_{h}}{N_{h}} I_{v}-\gamma E_{h}-\mu_{h} E_{h} \\
& \frac{d I_{h}}{d t}=\gamma E_{h}-\rho I_{h}-\mu_{h} I_{h} \\
& \frac{d R_{h}}{d t}=\rho I_{h}-\mu_{h} R_{h} \\
& \frac{d S_{v}}{d t}=A_{v}-b p_{v} S_{v} \frac{I_{h}}{N_{h}}+\eta I_{v}-\mu_{v} S_{v} \\
& \frac{d I_{v}}{d t}=b p_{v} S_{v} \frac{I_{h}}{N_{h}}-\eta I_{v}-\mu_{v} I_{v}
\end{aligned}
$$

\section{Analisis Kestabilan Titik Ekuilibrium Model SIR dan Bilangan Reproduksi $\boldsymbol{R}_{0}$}

Dari Model 1, diperoleh titik ekuilibrium bebas penyakit :

$$
E_{0}=\left(S_{h}, I_{h}, R_{h}, S_{v}, I_{v}\right)=\left(\frac{A_{h}}{\mu_{h}}, 0,0, \frac{A_{v}}{\mu_{v}}, 0\right)
$$

dan titik ekuilibrium endemik:

$$
\begin{aligned}
& E_{1}=\left(S_{h}{ }^{*} I_{h}{ }^{*}, R_{h}{ }^{*}, S_{v}^{*}, I_{v}^{*}\right) \\
& \operatorname{dimana}: \\
& S_{h}^{*}=\frac{N_{h} \mu_{v}\left(b A_{h} p_{v}+\eta \rho N_{h}+\eta \mu_{h} N_{h}+\rho \mu_{v} N_{h}+\mu_{h} \mu_{v} N_{h}\right)}{b p_{v}\left(b A_{v} p_{h}+\mu_{h} \mu_{v} N_{h}\right)} \\
& I_{h}^{*}=\frac{b^{2} A_{h} A_{v} p_{h} p_{v}-\eta \rho N_{h}{ }^{2} \mu_{h} \mu_{v}-\eta N_{h}{ }^{2} \mu_{h}{ }^{2} \mu_{v}-\rho N_{h}{ }^{2} \mu_{h} \mu_{v}{ }^{2}-N_{h}{ }^{2} \mu_{h}{ }^{2} \mu_{v}{ }^{2}}{p_{v}\left(\rho+\mu_{h}\right)\left(b A_{v} p_{h}+N_{h} \mu_{h} \mu_{v}\right) b} \\
& R_{h}^{*}=\frac{\rho\left(b^{2} A_{h} A_{v} p_{h} p_{v}-\eta \rho N_{h}{ }^{2} \mu_{h} \mu_{v}-\eta N_{h}{ }^{2} \mu_{h}{ }^{2} \mu_{v}-\rho N_{h}{ }^{2} \mu_{h} \mu_{v}{ }^{2}-N_{h}{ }^{2} \mu_{h}{ }^{2} \mu_{v}{ }^{2}\right)}{p_{v}\left(\rho+\mu_{h}\right)\left(b A_{v} p_{h}+N_{h} \mu_{h} \mu_{v}\right) b \mu_{h}} \\
& S_{v}^{*}=\frac{\left(b A_{v} p_{h}+N_{h} \mu_{h} \mu_{v}\right)\left(\eta \rho+\eta \mu_{h}+\rho \mu_{v}+\mu_{h} \mu_{v}\right) N_{h}}{\mu_{v} p_{h}\left(b A_{h} p_{v}+\eta \rho N_{h}+\eta \mu_{h} N_{h}+\rho \mu_{v} N_{h}+\mu_{h} \mu_{v} N_{h}\right) b} \\
& I_{v}^{*}=\frac{b^{2} A_{h} A_{v} p_{h} p_{v}-\eta \rho N_{h}{ }^{2} \mu_{h} \mu_{v}-\eta N_{h}{ }^{2} \mu_{h}{ }^{2} \mu_{v}-\rho N_{h}{ }^{2} \mu_{h} \mu_{v}{ }^{2}-N_{h}{ }^{2} \mu_{h}{ }^{2} \mu_{v}{ }^{2}}{\left(b A_{h} p_{v}+\eta \rho N_{h}+\eta \mu_{h} N_{h}+\rho \mu_{v} N_{h}+\mu_{h} \mu_{v} N_{h}\right) b \mu_{v} p_{h}}
\end{aligned}
$$

Selanjutnya dengan menggunakan metode The Next Generation Matrix (NGM) didefinisikan bilangan $R_{0}$ untuk model SIR yang merupakan nilai eigen terbesar dari NGM pada titik ekuilibrium bebas penyakit sebagai berikut: 


$$
\begin{gathered}
R_{0}=\frac{b \sqrt{N_{h}\left(\eta \rho+\eta \mu_{h}+\rho \mu_{v}+\mu_{h} \mu_{v}\right) p_{h} p_{v} N_{v}}}{N_{h}\left(\eta \rho+\eta \mu_{h}+\rho \mu_{v}+\mu_{h} \mu_{v}\right)} \\
R_{0}^{2}=\frac{b^{2} p_{h} p_{v} N_{v}}{N_{h}\left(\eta \rho+\eta \mu_{h}+\rho \mu_{v}+\mu_{h} \mu_{v}\right)}
\end{gathered}
$$

Teorema 1. Titik ekulibrium bebas penyakit $E_{0}$ akan stabil asimtotik lokal jika dan hanya jika $R_{0}<1$.

Teorema 2. Titik ekulibrium endemik $E_{1}$ akan stabil asimtotik lokal jika dan hanya jika $R_{0}>1$.

Teorema 3. Sebuah matriks $A$ memiliki nilai eigen negatif apabila diagonal utama matriks $(-A)>0$ dan $\operatorname{det}(-A)>0$

Bukti Teorema 1.

Diketahui $R_{0}<1$ akan ditunjukkan titik ekulibrium bebas penyakit $E_{0}$ stabil asimtotik lokal. Matriks Jacobian dari Sistem 1 di titik ekuilibrium $E_{0}$ adalah:

$$
\left(J E_{0}\right)=\left[\begin{array}{ccccc}
-\mu_{h} & 0 & 0 & 0 & -b p_{h} \\
0 & -\rho-\mu_{h} & 0 & 0 & b p_{h} \\
0 & \rho & -\mu_{h} & 0 & 0 \\
0 & -\frac{b p_{v} N_{v}}{N_{h}} & 0 & -\mu_{v} & \eta \\
0 & \frac{b p_{v} N_{v}}{N_{h}} & 0 & 0 & -\eta-\mu_{v}
\end{array}\right]
$$

Diagonal utama dari $\left(-J E_{0}\right)$ adalah

$$
\left(-J E_{0}\right)=\left[\begin{array}{c}
\mu_{h} \\
\rho+\mu_{h} \\
\mu_{h} \\
\mu_{v} \\
\eta+\mu_{v}
\end{array}\right]
$$

Diperhatikan bahwa entri diagonal utama $\left(-J E_{0}\right)>0$.

Selanjutnya determinan dari $\left(-J E_{0}\right)$ adalah :

$$
\left|\left(-J E_{0}\right)\right|=-\frac{\mu_{h}^{2} \mu_{v}\left(b^{2} p_{h} p_{v} N_{v}-\eta \rho N_{h}-\eta \mu_{v} N_{h}-\rho \mu_{v} N_{h}-\mu_{h} \mu_{v} N_{h}\right)}{N_{h}}
$$


dapat ditulis

$$
\begin{aligned}
&\left|\left(-J E_{0}\right)\right|-\frac{\mu_{h}{ }^{2} \mu_{v}\left(b^{2} p_{h} p_{v} N_{v}-\eta \rho N_{h}-\eta \mu_{v} N_{h}-\rho \mu_{v} N_{h}-\mu_{h} \mu_{v} N_{h}\right)}{N_{h}} \\
&=\left(\mu_{h}{ }^{2} \mu_{v}\right)\left[\left(\eta \rho+\eta \mu_{v}+\rho \mu_{v}+\mu_{h} \mu_{v}\right)\left(1-R_{0}{ }^{2}\right)\right] \\
& \text { karena: } 0<\mu_{h}{ }^{2} \mu_{v}<1 \\
&\left(1-R_{0}{ }^{2}\right)>0 \\
& R_{0}{ }^{2}<1 \text { karena diketahui } R_{0}<1
\end{aligned}
$$

Maka $\operatorname{det}\left(-J E_{0}\right)>0$. Sehingga berdasarkan Teorema 3, matriks $\left(-J E_{0}\right)$ memiliki nilai eigen negatif atau bagian real negatif, dan menurut Horn [5] terbukti bahwa titik ekuilibrium bebas penyakit $E_{0}$ stabil asimtotik lokal.

Selanjutnya diketahui $E_{0}$ stabil asimtotik lokal maka akan dibuktikan bahwa $R_{0}<1$, karena stabil asimtotik maka $\left(-J E_{0}\right)$ memiliki nilai eigen negatif. Menurut Teorema 3, diagonal utama $\left(-J E_{0}\right)>0 \operatorname{dan} \operatorname{det}\left(-J E_{0}\right)>0$

Determinan dari $\left(-J E_{0}\right)$ adalah :

$$
\left|\left(-J E_{0}\right)\right|=-\frac{\mu_{h}^{2} \mu_{v}\left(b^{2} p_{h} p_{v} N_{v}-\eta \rho N_{h}-\eta \mu_{v} N_{h}-\rho \mu_{v} N_{h}-\mu_{h} \mu_{v} N_{h}\right)}{N_{h}}
$$

dan telah diperoleh :

$$
\begin{gathered}
R_{0}=\frac{b \sqrt{N_{h}\left(\eta \rho+\eta \mu_{h}+\rho \mu_{v}+\mu_{h} \mu_{v}\right) p_{h} p_{v} N_{v}}}{N_{h}\left(\eta \rho+\eta \mu_{h}+\rho \mu_{v}+\mu_{h} \mu_{v}\right)} \\
R_{0}{ }^{2}=\frac{b^{2} p_{h} p_{v} N_{v}}{N_{h}\left(\eta \rho+\eta \mu_{h}+\rho \mu_{v}+\mu_{h} \mu_{v}\right)}
\end{gathered}
$$

Maka :

$$
\begin{aligned}
\left|\left(-J E_{0}\right)\right| & =-\frac{\mu_{h}{ }^{2} \mu_{v}\left(b^{2} p_{h} p_{v} N_{v}-\eta \rho N_{h}-\eta \mu_{v} N_{h}-\rho \mu_{v} N_{h}-\mu_{h} \mu_{v} N_{h}\right)}{N_{h}} \\
& =\left(\mu_{h}{ }^{2} \mu_{v}\right)\left[\left(\eta \rho+\eta \mu_{v}+\rho \mu_{v}+\mu_{h} \mu_{v}\right)\left(1-R_{0}{ }^{2}\right)\right]
\end{aligned}
$$

maka: $\mu_{h}^{2} \mu_{v}<1$ dan $\left(1-R_{0}^{2}\right)>0$, berarti $R_{0}^{2}<1$ maka $R_{0}<1$

Determinan $\left(-J E_{0}\right)>0$ apabila $R_{0}^{2}<1$ atau $R_{0}<1$, jelas bahwa $R_{0}<1$, sehingga Teorema 1 terbukti.

Dengan cara yang sama Teorema 2 dapat dibuktikan. 


\section{Simulasi Numerik Model SIR}

Selanjutnya dengan menggunakan data yang memenuhi Teorema 1, yaitu: $A_{h}=\mu_{h} \cdot N_{h}, p_{h}=0,01, \mu_{h}=0,0000392, A_{v}=\mu_{v} \cdot N_{v}, p_{v}=0.5, \mu_{v}=0.0111, \rho=$ $0,0333, \eta=0,3333, t=0 . .200, N_{h}=15000, N_{v}=5500, S_{h}=14998, I_{h}=2, R_{h}=$ $0, S_{v}=5498, I_{v}=2$, dan nilai awal yang sama untuk Teorema 2 serta nilai $p_{h}=0,5$ dan $p_{v}=0,25$, kestabilan dari titik ekuilibrium bebas penyakit (DFE) dan titik ekuilibrium endemik ((DEE) terlihat pada Gambar 3 berikut:

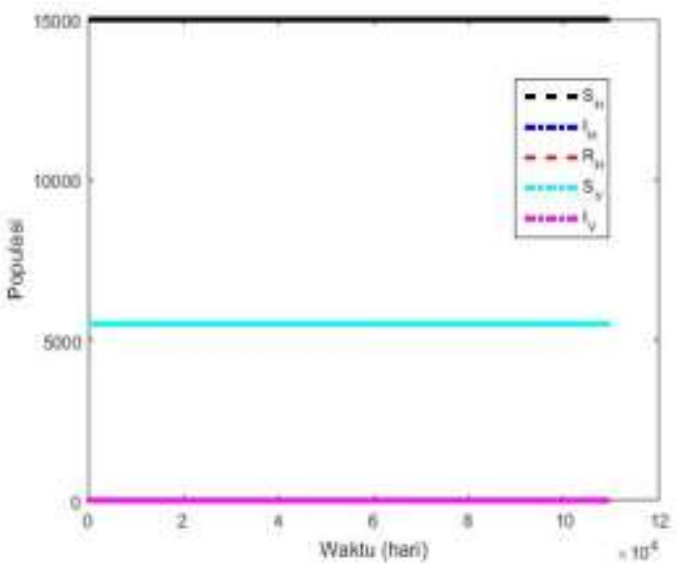

(a)

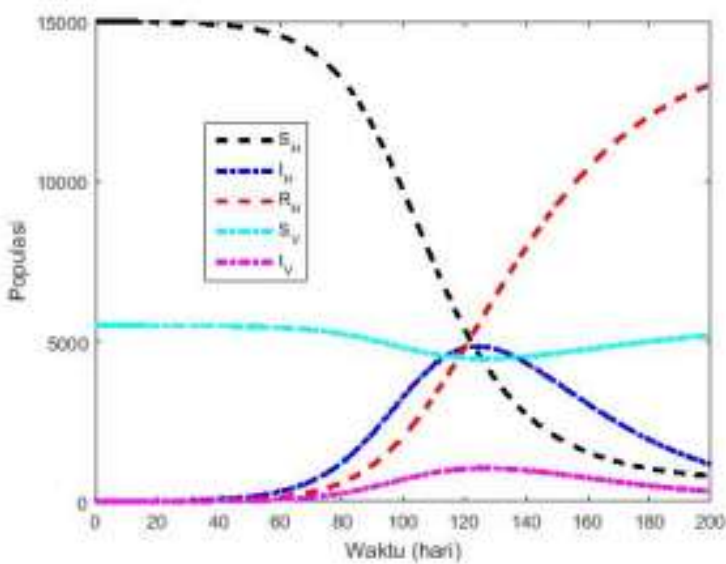

(b)

Gambar 3. (a) Grafik Kestabilan DFE pada Model SIR (b) Kestabilan DEE pada Model SIR

Dari Gambar 3 (a) terlihat bahwa untuk jangka waktu yang sangat lama maka populasi host dan vector akan konvergen ke DFE. Populasi susceptibe host akan menuju populasi awal, hal ini terjadi karena tidak adanya populasi terinfeksi. Populasi infective host dan recovered host juga mengalami penurunan. Populasi susceptible vector mengalami kenaikan karena beum terjadi infeksi dan populasi infetive vector akan mengalami penurunan menuju nol. Dari Gambar 3 (b) terlihat bahwa untuk jangka waktu yang sangat lama maka populasi host dan vector akan konvergen ke DEE.

\section{Analisis Kestabilan Titik Ekuilibrium Model SEIR}

Titik ekuilibrium bebas penyakit (DFE) dan titik ekuilibrium endemik (DEE) untuk model SEIR adalah:

$$
E_{0}=\left(S_{h}=N_{h}=\frac{A_{h}}{\mu_{h}}, E_{h}=0, I_{h}=0, R_{h}=0, S_{v}=N_{v}=\frac{A_{v}}{\mu_{v}}, I_{v}=0\right)
$$




$$
\begin{aligned}
& E_{1}=\left(S_{h}^{*}=\frac{N_{h} \mu_{v} A}{\gamma \sigma_{v} B}, E_{h}^{*}=\frac{F}{\gamma \sigma_{v} B C}, I_{h}^{*}=\frac{F}{\sigma_{v} B D}\right. \\
& \left.R_{h}^{*}=\frac{\rho F}{\sigma_{v} \mu_{h} B D}, S_{v}^{*}=\frac{B E N_{h}}{\theta_{h} \mu_{v} A}, I_{v}^{*}=\frac{F}{\theta_{h} \mu_{v} A}\right) \\
& A=\left(\begin{array}{l}
b \gamma A_{h} p_{v}+\eta \gamma \rho N_{h}+\eta \gamma \mu_{h} N_{h}+\eta \rho \mu_{h} N_{h}+\eta \mu_{h}^{2} N_{h} \\
+\gamma \rho \mu_{v} N_{h}+\gamma \mu_{h} \mu_{v} N_{h}+\rho \mu_{h} \mu_{v} N_{h}+\mu_{h}^{2} \mu_{v} N_{h}
\end{array}\right) \\
& B=b A_{v} p_{h}+\mu_{h} \mu_{v} N_{h} \\
& C=\gamma+\mu_{h} \\
& D=\gamma \rho+\gamma \mu_{h}+\rho \mu_{h}+\mu_{h}^{2} \\
& E=\eta \gamma \rho+\eta \gamma \mu_{h}+\eta \rho \mu_{h}+\eta \mu_{h}^{2}+\gamma \rho \mu_{h} \mu_{v}+\gamma \mu_{h} \mu_{v}+\rho \mu_{h} \mu_{v}+\mu_{h}{ }^{2} \mu_{v} \\
& F=\left(\begin{array}{l}
b^{2} \gamma A_{h} A_{v} p_{h} p_{v}-\eta \gamma \rho \mu_{h} \mu_{v} N_{h}{ }^{2}-\eta \gamma \mu_{h}^{2} \mu_{v} N_{h}{ }^{2}-\eta \rho \mu_{h}{ }^{2} \mu_{v} N_{h}{ }^{2} \\
-\eta \mu_{h}^{3} \mu_{v} N_{h}{ }^{2}-\gamma \rho \mu_{h} \mu_{v}{ }^{2} N_{h}{ }^{2}-\gamma \mu_{h}{ }^{2} \mu_{v}{ }^{2} N_{h}{ }^{2}-\rho \mu_{h}{ }^{2} \mu_{v}{ }^{2} N_{h}{ }^{2} \\
-\mu_{h}{ }^{3} \mu_{v}{ }^{2} N_{h}{ }^{2}
\end{array}\right) \\
& X=N_{h}^{2} \mu_{h} \mu_{v}\left(\begin{array}{l}
\eta \gamma \rho+\eta \gamma \mu_{h}+\eta \rho \mu_{h}+\eta \mu_{h}^{2}+\gamma \rho \mu_{h} \mu_{v} \\
+\gamma \mu_{h} \mu_{v}+\rho \mu_{h} \mu_{v}+\mu_{h}^{2} \mu_{v}
\end{array}\right) \\
& \theta_{h}=b p_{h} \\
& \sigma_{v}=b p_{v}
\end{aligned}
$$

Dengan menggunakan metode NGM diperoleh bilangan reproduksi dasar untuk model SEIR sebagai berikut:

$$
\begin{aligned}
& R_{0}=\frac{b \sqrt{N_{h}\left(\eta \gamma \rho+\eta \gamma \mu_{h}+\eta \rho \mu_{h}+\eta \mu_{h}^{2}+\gamma \rho \mu_{v}+\gamma \mu_{h} \mu_{v}+\rho \mu_{h} \mu_{v}+\mu_{h}^{2} \mu_{v}\right) \gamma p_{h} p_{v} N_{v}}}{N_{h}\left(\eta \gamma \rho+\eta \gamma \mu_{h}+\eta \rho \mu_{h}+\eta \mu_{h}^{2}+\gamma \rho \mu_{v}+\gamma \mu_{h} \mu_{v}+\rho \mu_{h} \mu_{v}+\mu_{h}^{2} \mu_{v}\right)} \\
& R_{0}^{2}=\frac{b^{2} \gamma p_{h} p_{v} N_{v}}{N_{h}\left(\eta \gamma \rho+\eta \gamma \mu_{h}+\eta \rho \mu_{h}+\eta \mu_{h}^{2}+\gamma \rho \mu_{v}+\gamma \mu_{h} \mu_{v}+\rho \mu_{h} \mu_{v}+\mu_{h}^{2} \mu_{v}\right)}
\end{aligned}
$$

Teorema 1 dan Teorema 2 juga berlaku untuk model SEIR dan dapat dibuktikan dengan dengan cara yang sama seperti pada model SIR. 


\section{Simulasi Numerik Model SEIR}

Nilai parameter yang digunakan untuk model SEIR adalah sebagai berikut $A_{h}=\mu_{h} \cdot N_{h}, p_{h}=0,01, \mu_{h}=0,0000392, A_{v}=\mu_{v} \cdot N_{v}, p_{v}=0.5, \mu_{v}=0.0111, \rho=$ $0,0333, \eta=0,3333, t=0 . .200, N_{h}=15000, N_{v}=5500, S_{h}=14996, E_{h}=2, I_{h}=$ $2, R_{h}=0, S_{v}=5498, I_{v}=2$, dan $\gamma=0,0005479$ karena sesuai dengan waktu inkubasi virus HIV paling sedikit lima tahun.

Hasil Simulasi numerik untuk model SEIR terlihat pada Gambar 4 berikut:
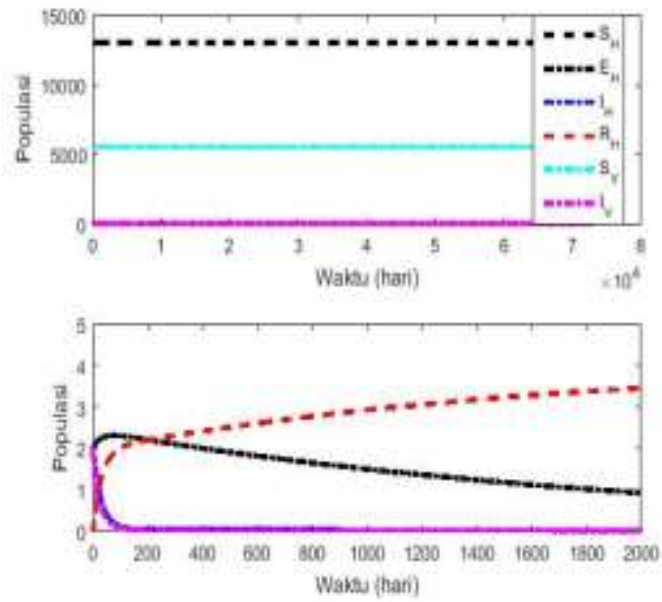

(a)

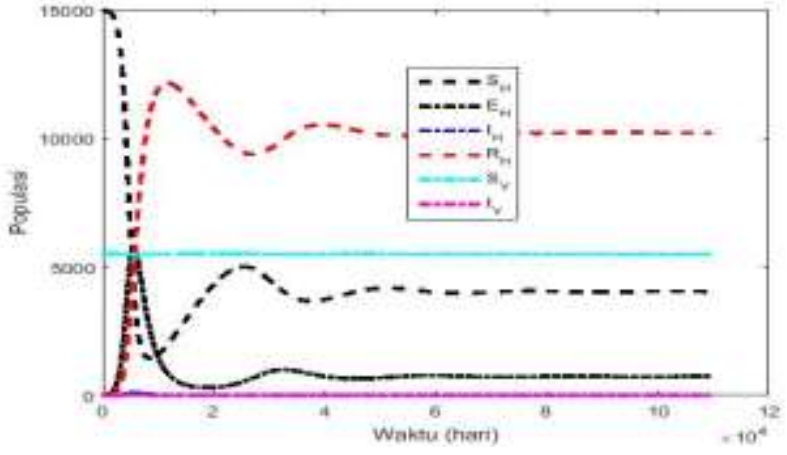

(b)

Gambar 4. (a) Grafik Kestabilan DFE pada Model SEIR (b) Kestabilan DEE pada Model SEIR

Dari Gambar 4 (a) terlihat bahwa pada model SEIR untuk jangka waktu yang lama populasi host dan vector akan konvergen ke DFE. Gambar 4 (b), populasi susceptible host akan mengalami penurunan karena terjadi kontak denga populasi infective vector. Selain itu terjadi penurunan karena adanya kematian alami. Laju pertumbuhan populasi exposed host awalnya mengalami peningkatan tetapi semakin lama mengalami penurunan karena populasi tersebut sudah terjadi perpindahan ke infective host dan juga adanya kematian alami. Populasi infective host awalnya juga mengalami kenaikan kemudian mengalami penurunan karena adanya perpindahan populasi yang mengalami masa pemulihan ke recoverd host. Laju pertumbuhan populasi infective vektor mengalami penurunan dari jumlah awalnya karena terjadi kerusakan dan adanya sterilisasi jarum suntik. 


\section{Analisa Sensitivitas}

Analisa sensitivitas dilakukan untuk melihat parameter-parameter mana yang mempengaruhi $R_{0}$. Dalam penelitian ini dilakukan analisa sensitivitas $\mathrm{R}_{0}$ dan $\psi$ dengan $\psi=\frac{N_{v}}{N_{h}}, R_{0}$ dan $\rho, R_{0}$ dan $\eta, R_{0}$ dan $b p_{h}, R_{0}$ dan $b p_{v}$, dan juga dilihat hubugan antar parameter terhadap nilai $R_{0}$ yang berbeda yaitu $b p_{h}$ dan $b p_{v}, b p_{h}$ dan $\rho, b p_{h}$ dan $\eta$ , $b p_{v}$ dan $\rho, b p_{v}$ dan $\eta, \psi$ dan $\rho, \psi$ dan $\eta, \psi$ dan $b p_{h}, \psi$ dan $b p_{v}$. Dari hasil analisa sensitivitas diperoleh parameter yang paling berpengaruh adalah $b p_{h}$ dan $b p_{v}$.

Hal ini menggambarkan bahwa semakin besar laju infeksi virus pada manusia oleh jarum suntik, maka semakin besar penyebaran HIV/AIDS yang terjadi dan semakin besar laju infeksi virus pada jarum suntik dari manusia yang terinfeksi maka semakin besar penyebaran HIV/AIDS yang terjadi.

\section{Simpulan dan Saran}

Berdasarkan hasil analisi dan hasil simulasi numerik titik ekuilibrium bebas penyakit akan stabil asimtotik lokal jika $R_{0}<1$ dan titik endemik ekuilibrium akan stabil asimtotik lokal jika $R_{0}>1$.

Hasil analisa sensitivitas juga menunjukkan bahwa parameter yang paling berpengaruh terhadap $R_{0}$ adalah parameter $b p_{h}$ dan $b p_{v}$ artinya untuk meminimalkan penyebaran HIV/AIDS pada pengguna jarum suntik perlu dilakukan beberapa hal seperti menghindari penggunaan jarum suntik di antara sesama pengguna napza, atau melakukan sterilisasi terhadap jarum suntik.

\section{Daftar Pustaka}

[1] D. Greenhalgh and G. Hay, Mathematical Modelling of the Speard of HIV/AIDS Amongs Injecting Drug Users, IMA Journal of Mathematics Applied in Medicine and Biology, Vol 14 pp 11-38, 1997.

[2] Besral, Budi U. dan Andri P.M, Potensi Penyebaran HIV dari Pengguna Napza Suntik ke Masyarakat Umum, Makara Journal of Health Research, Vol.8 No.2 pp 53-58, 2004.

[3] Kementerian Kesehatan R.I, Laporan Situasi Perkembangan HIV/AIDS di Indonesia Sampai September 2014, Jakarta Pusat, 2014.

[4] P.van den D and J. Watmough, Reproduction Numbers and Subthreshold Endemic Equilibra for Compartmental Model of Disease Trasmission, Math Bioscience. 180 29-48, 2002.

R. A. Horn and C.R Johnson, Matrix Analysis, Cambridge University Press, 1990. 